Volume 9

Number 12009

Article 1

December 2009

\title{
Realizing Potential: A Pragmatic Look at Human Embryonic Stem Cell Research
}

Mark Bentley

Cedarville University

DigitalCommons@Cedarville provides a publication platform for fully open access journals, which means that all articles are available on the Internet to all users immediately upon publication. However, the opinions and sentiments expressed by the authors of articles published in our journals do not necessarily indicate the endorsement or reflect the views of DigitalCommons@Cedarville, the Centennial Library, or Cedarville University and its employees. The authors are solely responsible for the content of their work. Please address questions to dc@cedarville.edu.

\section{Recommended Citation}

Bentley, Mark (2009) "Realizing Potential: A Pragmatic Look at Human Embryonic Stem Cell Research," CedarEthics: A Journal of Critical Thinking in Bioethics: Vol. 9 : No. 1 , Article 1.

DOI: $10.15385 /$ jce.2009.9.1.1

Available at: http://digitalcommons.cedarville.edu/cedarethics/vol9/iss1/1 


\title{
Realizing Potential: A Pragmatic Look at Human Embryonic Stem Cell Research
}

Browse the contents of this issue of CedarEthics: A Journal of Critical Thinking in Bioethics.

\begin{abstract}
In the United States, there are over 400,000 cryogenically frozen embryos (Hoffman, et al., 2003). These frozen embryos are almost exclusively produced from in vitro fertilization (IVF) and related treatments. Much debate centers on the fate of these embryos. Among the current options available to the parents of leftover embryos are embryo adoption, keeping the embryos frozen for future use, destroying them, fauximplantations to let the embryos "naturally" die (Grady, 2008), and donating them for human embryonic stem cell (hES cell) research. While not all of the embryos are destroyed, many are, and it is wasteful for those embryos to simply be discarded. With the consent of the parents, researchers should use the embryos slated to be destroyed or discarded for the purpose of realizing the great potential they posses, rather than letting them be wasted.
\end{abstract}

\section{Keywords}

Embryonic stem cell research, ethics, frozen embryos, IVF

\section{Creative Commons License}

\section{(c) $10 \Theta \Theta$}

This work is licensed under a Creative Commons Attribution-Noncommercial-No Derivative Works 3.0 License.

Follow this and additional works at: http:// digitalcommons.cedarville.edu/cedarethics

Part of the Bioethics and Medical Ethics Commons 


\title{
Realizing Potential: A Pragmatic Look at Human Embryonic Stem Cell Research
}

\author{
Mark L. Bentley \\ Cedarville University
}

$\lceil$ ( n the United States, there are over 400,000 cryogenically frozen embryos (Hoffman, et al., 2003). These frozen embryos are almost exclusively produced from in vitro fertilization (IVF) and related treatments. Much debate centers on the fate of these embryos. Among the current options available to the parents of leftover embryos are embryo adoption, keeping the embryos frozen for future use, destroying them, faux-implantations to let the embryos „naturally" die (Grady, 2008), and donating them for human embryonic stem cell (hES cell) research. While not all of the embryos are destroyed, many are, and it is wasteful for those embryos to simply be discarded. With the consent of the parents, researchers should use the embryos slated to be destroyed or discarded for the purpose of realizing the great potential they possess, rather than letting them be wasted.

Thousands of embryos created via IVF are destroyed or discarded each year (Harvard, 2008). In fact, over the last 14 years there have been over one million embryos destroyed in the UK alone (Woolf, 2007). Many frozen embryos are destroyed because of circumstances: the death of the donor parents, loss of contact with the parents, divorce, or the parents simply do not want to use the embryos or put them up for adoption. Some say that the surplus frozen embryos should be placed for adoption instead of being destroyed. However, while there are several groups working for and towards this end, for every embryo that is donated to others, more than 100 embryos are still discarded (Michigan, 2009). There simply are not enough people willing to adopt all of the existing unused embryos.

Numerous embryos also are discarded as medical waste because they cannot be used for fertility treatments, due to genetic defects or abnormal development. These embryos, while unfit for IVF because they either will not implant in the uterus, or have a much lower chance for implantation, can be used as a source of hES cells. Even in nature, these embryos would have the same lowto no- implantation rate, or would be subject to spontaneous abortion. Thus, in any scenario, these embryos have very little, if any, chance of survival. They are not being used. They are not even being stored as the healthy embryos that are often later destroyed, and they also would have been destroyed naturally had their conception taken place in vivo.

In addition to circumstances, genetic defects, and abnormal development, there are many other reasons that embryos are destroyed, but whatever the reason, embryos are being destroyed or discarded. In this context the question is not "should these embryos have been created?" Nor is it "should they be destroyed?" They were created, and they are being destroyed. The question is, why shouldn't they be used for good?

First, one might argue that we do not have the power to choose how the embryos are used because the embryos cannot give consent. Let's assume, for the sake of analogy, that a man is unconscious, and being kept alive by life support systems. The doctor informs the man's wife 
that he will not regain consciousness, and will remain in this state as long as she keeps the life support systems on. For ethically reasonable and justifiable reasons, she decides to withdraw the life support, and then informs the doctor that she would like to donate his organs. This is carried out, and many lives are saved.

Donating embryos that are slated for destruction is similar to donating the organs or body of an individual who is dying. In the case of the organ or body donor, we do not always require the consent of the individual, as in the above analogy. In the absence of a living will, a surrogate often has to decide on behalf of a person who is unconscious. In case of the embryos, the parents make the decision of what to do with the embryos. The parents may decide, instead of simply destroying the embryos, to let them be used in ways that can benefit others. In fact, about $66 \%$ of patients say they are willing to donate embryos for stem cell research (Grady, 2008).

While it is true that $\mathrm{hES}$ cell research destroys persons, it is also true that only two options exist: these persons can be destroyed with no possibility of benefit to others, or they can be destroyed with great possibility of benefit to others. The ethics of taking human life are clear. However, when the option to save the life does not exist, is it not possible that deciding on behalf of other people that their deaths will be useless, when they cannot decide for themselves, also unethical?

Second, one might argue that hES cell research itself is unnecessary because hES cells are not the only type of stem cell research being pursued. However, the research related to hES cells has been largely impaired, not because hES cell research does not have enormous potential (Andrews, et al., 2005), but because of the ethical debate centered on hES cell research (Abhishek, 2008). That debate has been the reason behind the recent initiative to find alternatives for hES cells in regenerative medicine (Abhishek, 2008). Alternatives include Pluripotent Aminotic Epithelium Cells, Trophoblast-derived Stem Cells, Endometrial Regenerative Cells, Placental-derived Stem Cells, Umbilical Cord Blood Stem Cells, Amniotic Fluid Stem Cells, Adult Stem Cells, and Induced Pluripotent Stem Cells (Abhishek, 2008). Some of these alternatives show great promise, but still researchers hold them to the benchmark of the potential of hES cell research. For example, research is being conducted using embryonic stem cells to cure kidney, liver, heart, blood, nervous system, and other diseases and injuries (Leslie, 2006).

The researchers hypothesize that stem cells from just one particular source won't be able to cure all of these diseases, but rather that "most likely, each disease will have its own preferred source," (Van de Stolpe, et al., 2005). Further, recent studies have shown that we are getting closer to realizing some of the potential of hES cells. Leslie (2006) cites several examples of $\mathrm{hES}$ cell advances, such as genetic marker recognition, production of ectodermal, mesodermal, and endodermal lineages, and even disease-specific lines of $\mathrm{hES}$ cells.

Additionally, Hyun (2009) argues that other promising forms of stem cell research, specifically induced pluripotent stem (iPS) cells, requires that hES cells develop alongside iPS cells to better understand the iPS cell technology. "[T]he use of human embryonic stem cells is absolutely essential in increasing our understanding of iPS cells." Hyun argues: "if you are going to make an artificial version of a human embryonic stem cell, you had better know everything you can learn about the real deal" (Hyun, 2009). 
I am not arguing that embryos should be created with the sole purpose of being used in hES cell research, that we establish labs to create embryos for research purposes only. Neither am I arguing that we should encourage the destruction of embryos, or that we should use embryos that might be destroyed. hES cell research should only use embryos that are being destroyed, and the embryos must be willingly donated by parents for the purpose of research that could potentially save many lives and cure diseases. Under these circumstances, hES cell research does not have to be an additional destruction of life. Rather, if realized, the potential that hES cell research holds could save the lives, or significantly improve the quality of life, for millions of people.

\section{References}

Garg, A. (2008). Stem Cell Therapeutics: Exploring Newer Alternatives to Human Embryonic Stem Cells. Internet Journal of Health, 8(1), 16. http://search.ebscohost.com

Andrews, P., Benvenisty, N., McKay, R., Pera, M., Rossant, J., Semb, H., et al. (2005). The International Stem Cell Initiative: toward benchmarks for human embryonic stem cell research. Nature Biotechnology, 23(7), 795-797.

Czyz, J., Wiese, C., Rolletschek, A., Blyszczuk, P., Cross, M., \& Wobus, A. (2003). Potential of Embryonic and Adult Stem Cells in vitro. Biological Chemistry, 384(10/11), 1391-1409.

Grady, D. (2008, December 4). Parents torn over fate of frozen embryos. The New York Times, p. A26.

Harvard University. (2008). Stem cell lines created from discarded IVF embryos. Retrieved November 3, 2009, from http://www.physorg.com/news121446759.html.

Hoffman, D., Zellman, G., Fair, C., Mayer, J., Zeitz, J., Gibbons, W, \& Turner, T. (2003). Cryopreserved embryos in the United States and their availability for research. Fertility and Sterility, 79 (5), 1063-1069.

Hyun, I. (2009). Clarifying the President's Council's clarification of the Obama stem cell policy. Retrieved November 3, 2009, from http://www.thehastingscenter.org/Bioethicsforum/Post.aspx?id=3308

Kline, L. B. (2009). National survey reveals growing preference for human embryo donation/adoption among Americans. Reuters. Retrieved November 3, 2009, from http://www.reuters.com/article/pressRelease/idUS154239+13-Oct-2009+BW20091013.

Koestenbauer, S., Zech, N., Juch, H., Vanderzwalmen, P., Schoonjans, L., \& Dohr, G. (2006). Embryonic Stem Cells: Similarities and Differences Between Human and Murine Embryonic Stem Cells. American Journal of Reproductive Immunology, 55(3), 169-180. 
Leslie, M. (2006). The action behind the words: embryonic stem cell research marches on. Journal of Cell Biology, 174(6), 743-746.

Regents of the University of Michigan. (2009). Stem cell research: Frequently asked questions. Retrieved November 3, 2009, from http://www.umich.edu/stemcell/faq/.

van de Stolpe, A., van De Brink, S., van Rooijen, M., Ward-van Oostwaard, D., van Inzen, W., Slaper-Cortenbach, I., et al. (2005). Human embryonic stem cells: towards therapies for cardiac disease. Derivation of a Dutch human embryonic stem cell line. Reproductive BioMedicine Online, 11(4), 476-485.

Woolf, M. (2007, December 30). IVF clinics destroy 1m „waste“ embryos. Times Online. Retrieved November 3, 2009, from http://www.timesonline.co.uk/tol/life and style/health/article310 8160.ece 